\title{
Cultural Communication and Socialization
}

\section{Journal (CCSJ)}

ZIBELINE INTERNATIONAL

ISSN: 2735-0428 (Online)

DOI: http://doi.org/10.26480/cssj.02.2021.43.47

\section{CODEN: CCSJAJ}

RESEARCH ARTICLE

\section{VALIDATION OF THE FACTOR STRUCTURE OF THE HINDI VERSION OF RESILIENCE SCALE OF ADOLESCENTS IN THE INDIAN CONTEXT}

\author{
Shweta Singh and Ajai Pratap Singh* \\ Department of Applied Psychology, VBS Purvanchal University, Jaunpur, India \\ *Corresponding Author e-mail: ajaisingh27@gmail.com
}

This is an open access article distributed under the Creative Commons Attribution License CC BY 4.0, which permits unrestricted use, distribution, and reproduction in any medium, provided the original work is properly cited.

\section{ARTICLE DETAILS}

\section{Article History:}

Received 18 February 2021 Accepted 16 March 2021

Available online 20 April 2021

\begin{abstract}
The present study was designed to adapt a Resilience Scale, which examines the resilience level in adolescents of India's Hindi speaking states. In the present study, 14 items from the Resilience Scale-R25, developed by Wagnild and Young (1993), were adapted in Hindi language in the Indian context. A total 1000 adolescent students from different Hindi speaking states of India responded to the R14 scale. To test the factorial structure of the R14, an Exploratory Factor Analysis (EFA) and a Confirmatory Factor Analysis (CFA) were performed, and the internal consistency of the scale was studied. The results supported scale multidimensionality. The obtained Cronbach's alpha revealed good internal consistency with a value of .78. Based on the psychometric properties, it is concluded that R14 is a reliable measure to assess the resilience of the adolescents of Hindi speaking states of India.
\end{abstract}

\section{KEYWORDS}

Resilience Scale, Indian Context, Exploratory Factor Analysis (EFA), Confirmatory Factor Analysis (CFA)

\section{INTRODUCTION}

Resilience is not just about "bouncing back." It is about "bouncing forward." Resilience does not just mean getting back to normal after facing a difficult situation. It means learning from the process in order to become stronger and better at tackling the next challenge. Resiliency is one of the usual concepts and constructs studied in optimistic psychology, and it refers to successful adaptation in the presence of threats and challenges (Hanewald, 2011). Resiliency is passive resistance against threatening conditions and damages, but only the resilient person has active participation in his surrounding environment (Jokar, 2007). This construct is particularly important in the middle of adolescence because this period is accompanied by extensive social, biological, cognitive, and neurotic changes. In this period, adolescents pass childhood entirely and enter a new stage in which they encounter many problems (Khabbaz, Behjati, and Naseri, 2011). On the other hand, as Smith and Carlson (1997) mentioned, adolescents consider stressful events more than adults. They may have unhealthy behaviors or negative attitudes (Smokowski, Reynolds, and Bezruczko, 2000). As one of the protective factors against risky factors in the future, resiliency in adolescents, especially those in the middle of this period, is a new area paid attention by researchers. According to most researchers, resiliency is a good idea with high applied value for helping people while facing difficulties and protecting them against dangers during their lives (Khabbaz, Behjati, and Naseri, 2011). Lack of resiliency in the middle of adolescence can result in impulsiveness, weak reactive control, and internal problems (Smiley, 2011).

Adolescents mark the developmental transition from childhood to adulthood, where many crucial social, economic, biological, and demographic events set the stage for adult life. In contemporary India, while adolescence is a comparatively new term, the word youth is better known and used at policy formulation and programming levels. However, even the ancient text of Dharmashastra recognized the crucial nature of adolescence and prescribed specific codes of conduct for the phase. These codes are deeply rooted in the Indian psyche and continue to influence adolescents' cultural practices robustly. To contextualize the cultural milieu in which adolescents grow in India, the relevant traditional cultural values and themes that shape and affect adolescents' environment during their growing years need to be described. The family universally is acknowledged as an institution of socialization.

Resilient adolescents have unique features, such as social competence, independence, discipline, patience, optimism, and high intelligence. They are good at problem solving. Having a target and personal control, high self esteem, and concentration on strengths are other resilient adolescents' features. Their families have mutual emotion and affection with their parents (Kiani, 2004).

The literature on the topic has shown that it is important to develop reliable and valid measures able to assess this construct (Windle, Bennett \& Noyes, 2011), in different age groups and contexts (Felgueiras, Festas \& Vieira, 2010).

Within the scales developed to assess the perception that an individual has of himself as able (or not) to deal with any problematic situations and/or unforeseen circumstances, to be perseverant, autonomous, and have a positive perception of himself, the Resilience Scale stands out, developed by Wagnild and Young, in 1993, in the United States. Wagnild and Young (1993) define resilience as the ability to deal with change or adversity, effectively, or even as a positive feature of personality, promoting individual adaptation (Wagnild, 2009a).

The first resilience scale consisted of 50 items. After initial factor analysis, the scale was reduced to 25 items that reflected five basic characteristics of resilience: Perseverance, Self-confidence, Serenity, Meaning, and Existential Loneliness (Wagnild \& Young, 1990, 1993). The authors of the 
scale applied it on a sample consisting of 810 middle-aged adults. Results obtained from a principal component analysis (PCA with Oblique rotation), indicated the existence of two main factors, referred to as IPersonal Competence, and Factor II-Acceptance of themselves and of Life. These factors explained $44 \%$ of the total variance (Wagnild \& Young, 1993). The factor I was composed of 17 items that reflected selfconfidence, independence, mastery, resourcefulness, and perseverance. With 8 items, Factor II represented the ability to adapt, balance, flexibility, and a balanced perspective on life. Wagnild (2009b), resilience scale had already been applied to various population groups of different ages: adolescents, adults and the elderly, including risk populations and mothers with children in pre-school age with translations and adaptations for more than a dozen countries. These studies have found Cronbach's alpha between .72 and .94, which attested the good internal consistency of the RS25, demonstrating that this was a good scale to apply in different age groups and ethnicities (Wagnild, 2009b). However, Wagnild (2009a), in the user's guide of the scale, highlighted the existence of a unifatorial scale structure, and recommended that its quote should take into account a total score.

Felgueiras et al. (2010), in a sample of adolescents, and Oliveira \& Machado (2011), on a sample of university students, found a multidimensional structure of five factors, which presented good psychometric properties. Later, and using exploratory factor analysis, Pinheiro and Matos (2013a, 2013b) redefined some items and studied the RS's construct validity for a sample of Portuguese adolescents. This investigation gave rise to an extended version, of 23 items and a short version, of 13 items, with a unifatorial structure. Concerning reliability, excellent internal consistency was found for RS23 (Alpha equal to .95) and for RS13 (Alpha equal to .93) (Pinheiro \& Matos, 2013a, Pinheiro \& Matos, 2013a, 2013), in line with the values already found in other studies (Abiola \& Udofia, 2011; Felgueiras et al., 2010; Pesce et al., 2005; Wagnild \& Young, 1993).

\section{OBJECTIVE}

The present study aims to explore the factorial structure of R25 through an Exploratory Factor Analysis (EFA) and a Confirmatory Factor Analysis (CFA).

\section{Method}

\subsection{Participants}

Data was collected on a sample of 1000 adolescent students from different colleges of Hindi speaking states of India.

\subsection{Instruments}

The original scale of the Resilience has 25 items developed by Wagnild \& Young in 1993. Items are rated on 7-point Likert scale. The total scale ranges between 25 and 175 points (Wagnild and Young, 1993). The original RS indicated good psychometric properties for internal validity and content validity. A Cronbach's alfa of .91 was found, and item-total correlations ranged between .37 and .75 (Wagnild, 1993). It is composed of a unifatorial structure that includes self-esteem, independence, mastery, resourcefulness, perseverance, adaptability, balance, flexibility, and a balanced perspective on life (Wagnild, 2009a, 2009b; Wagnild \& Young, 1993). As for the local requirement, 14 items were chosen from the original scale and were adapted in Hindi. Items are rated on a 5-point response scale. The total score range between 14 and 70 . The adopted RS indicated good psychometric properties concerning internal validity and content validity. A Cronbach's alfa of .78 was found, and item-total correlations ranged between .39 and .46 (Wagnild, 1993). It is composed of a five factorial structure that includes items measuring preservence, self-reliant, interest in life, self-confidence \& accomplishment, and selfdetermination.

\subsection{Methodological Procedure}

Data collection was conducted from different colleges of Hindi speaking states of India. The questionnaire was delivered to the students. Before starting the infill, the following description could be read: "Please carefully read each of the following statements and answer them about you, the way you think, feel and act." Individuals should respond according to the degree to which they considered the items to better describe them.

\subsection{Statistical Procedure}

A sample of 1000 adolescents was used to carry out the Exploratory Factor Analysis (EFA). The minimum and maximum values and means and standard deviations were yielded for the total sample for descriptive analysis.

In the analysis of dimensionality of the 14 items of the Resilience Scale (RS14), an exploratory factor analysis (EFA) was conducted, using the computer program SPSS (Statistical Package for the Social Sciences version 16.0 for Windows)

The RS14 was studied using a principal components analysis, followed by a varimax rotation. The selection of the number of factors to be rotated was based on the Kaiser criteria of five factors. Items were kept based on factorial weights, commonalities, item-total correlations, and alfa values if the item was deleted. To ensure the data's adequacy, the Kaiser-MeyerOlkin (KMO) test was used, which ranges between 0 and 1, being .60 the minimum value to consider the analysis good (Tabachnick \& Vivek, 2011). Pestana \& Gageiro (2005) reported that values below.50 are unacceptable, between .50 and .60 are considered bad, from .60 to .70 acceptable, between .70 and .80 medium, from .80 to .90 good and values above .90 are considered very good. Bartlett's Test of Sphericity was also used to test the data's adequacy to perform factor analysis.The internal consistency (reliability) of the scale was calculated using Cronbach's alpha (value .78 is considered reliable, according to Pestana and Gageiro, 2003). Concerning item-total correlations, values below 0.30 suggest that it may be more suitable to eliminate the item (Osborne \& Castello, 2005).

To perform the confirmatory factor analysis (CFA), the computer software SPSS AMOS, version 18 for Windows, was used. Firstly, the assumptions underlying this analysis were verified, considering the absolute values of skewness (Sk) and kurtosis (Ku). Sk values $>|3|$ and Ku values $>|10|$ indicate violations of principles of normality (Kline, 2005). Mahalanobis distance $\left(\mathrm{MD}^{2}\right)$ was analyzed to identify possible outliers. The quality of adjustment of the model was evaluated based on a number of measures: the Chi-square ( $\chi 2 / \mathrm{df})$, Goodness-of-Fit Index (GFI), Normed Fit Index (NFI), Comparative Fit Index (CFI), Tucker-Lewis Index (TLI), Parsimony comparative fit index (PCFI), Parsimony Goodness-of-Fit Index (PGFI) and Root Mean Square of Approximation (RMSEA). To evaluate the model's adjustment, the following values were considered: $\chi 2 / \mathrm{df}$ inferior to 2 was considered good, TLI and CFI were considered good when superior to .90 (Kline, 2005; Maroco, 2010). GFI varies between 0 and 1, considering that the closer to 1, the better the adjustment of the model (Maroco, 2010). PNFI was considered good if superior to .60 and very good if higher than .80. For the PGFI and PCFI, the indexes are considered good when between .60 and .80 and very good if over .80 (Maroco, 2010). When it comes to RMSEA, values between .05 and .10 were considered good, and values lower than .05 were considered very good (Maroco, 2010; Meyers, Gamst, \& Guarino,2013). After the CFA was conducted, the adjustment indices, the factorial weights $(\lambda \geq .40)$, and individual reliabilities $\left(R^{2} \geq 0.25\right)$ were analyzed (Maroco, 2010).

\section{RESULTS}

\subsection{Exploratory factor analysis (EFA)}

The exploratory factor analysis (EFA) aimed to test the factorial structure proposed by the original authors, Wagnild \& Young (1993), and consequently validate it for adolescents of the Hindi speaking states of India. For this purpose, we used a sample of 1000 adolescents.

In the first principal component analysis, the viability of EFA was guaranteed using the KMO test (.868), considered acceptable, and Bartlett's Sphericity Test $[\chi 2(1000)=2.088 ; \mathrm{p}<.001]$, which proved to be significant. According to Kline (2005), all individual items presented values do not overly differ from the values considered appropriate, allowing to affirm that there was no violation of normality principles.

The set of 14 items from the RS was subjected to principal component factor analysis, using a varimax rotation and structure of five factors that explained $55.904 \%$ of the total variance was found.

The below table shows that the items on preservence dimension are five; self-reliance are three; interest in life are two, self-confidence \& accomplishment are two and self-determination are two. If you have strong theoretical and practical reasons, a factor can contain two items (Gosling, Rentfrow \& Swann Jr. 2003). 
Table 1: Factorial Weights and Commonalities $\left(\mathrm{h}^{2}\right)$

\begin{tabular}{|c|c|c|c|c|}
\hline Item No. & Items & Dimensions & Factorial Weight $\lambda$ & Commonalities $\mathbf{h}^{2}$ \\
\hline 2. & $\begin{array}{l}\text { I usually manage one way or another (प्राय: मैं किसी न किसी प्रकार से } \\
\text { कार्य संपन्न कर लेता/लेती हूँ|) }\end{array}$ & Self-reliance & .528 & .278 \\
\hline 3. & $\begin{array}{l}\text { I am able to depend myself more than anyone else (अन्य की तुलना } \\
\text { में, मैं स्वयं पर अधिक निर्भर हूँ।) }\end{array}$ & Self-reliance & .827 & .683 \\
\hline 4. & $\begin{array}{l}\text { Keeping interested in things is important to me (चीजों में रूचि बनाये } \\
\text { रखना मेरे लिए महत्वपूर्ण है।) }\end{array}$ & Interest in life & .738 & .544 \\
\hline 5. & $\begin{array}{l}\text { I can be on my own if I have to (यदि मुझे कार्य करना ही हो तो मैं स्वत: } \\
\text { कर सकता/सकती हूँ।) }\end{array}$ & Self-reliance & .555 & .308 \\
\hline 6. & $\begin{array}{l}\text { I feel proud that I have accomplished things in my life (मुझे इस बात } \\
\text { पर गर्व का अनुभव होता है कि मैने जीवन में कई कार्यो को सम्पन्न किया है।) }\end{array}$ & $\begin{array}{l}\text { Self-confidence and } \\
\text { accomplishment }\end{array}$ & .551 & .303 \\
\hline 7. & $\begin{array}{l}\text { I usually take things in stride (मैं प्राय: चीजों को शीघ्रता से करता/करती } \\
\text { हूँ।) }\end{array}$ & $\begin{array}{l}\text { Self-confidence and } \\
\text { accomplishment }\end{array}$ & .814 & .662 \\
\hline 10. & I am determined (मैं हढ़प्रतिज्ञ हूँ।) & Self determination & .823 & .677 \\
\hline 14. & I keep interested in things (मैं चीजों में रूचि बनाये रखता/रखती हूँ।) & Interest in life & .777 & .603 \\
\hline 16. & $\begin{array}{l}\text { My belief in myself gets me through hard times (मेरा आत्मविश्वास } \\
\text { मुझे बुरे वक्त को पार करा देता है।) }\end{array}$ & Perseverance & .457 & .208 \\
\hline 17. & $\begin{array}{l}\text { In an emergency, I'm someone people generally can rely on (किसी } \\
\text { आपात स्थिति में, मैं एक ऐसा/ऐसी व्यक्ति हू,, जिसपर लोग सामान्यत: भरोसा } \\
\text { कर सकते हैं।) }\end{array}$ & Self determination & .474 & .224 \\
\hline 18. & $\begin{array}{l}\text { I can usually look at a situation in a number of ways (किसी परिस्थिति } \\
\text { को मैं अलग-अलग नजरिये से देख सकता/सकती हूँ।) }\end{array}$ & Perseverance & .538 & .289 \\
\hline 19. & My life has meaning (मेरा जीवन उद्देश्यपूर्ण है।) & Perseverance & .672 & .451 \\
\hline 20. & $\begin{array}{l}\text { When I'm in a difficult situation, I can usually find my way out of it } \\
\text { (जब मैं किसी कठिन परिस्थिति में होता/होती हूँ तो मैं सामान्यत: बाहर } \\
\text { निकलने का रास्ता तलाश लेता/लेती हूँ।) }\end{array}$ & Perseverance & .674 & .454 \\
\hline 21. & $\begin{array}{l}\text { I have enough energy to do what I have to do (मुझे जो करना होता है } \\
\text { उसके लिए मेरे पास पर्याप्त उर्जा होती है।) }\end{array}$ & Perseverance & .670 & .446 \\
\hline
\end{tabular}

The properties of the items and internal consistency were studied through the analysis of the means and standard deviation of the item, the item-total correlations, and Cronbach's alpha value if the item was to be deleted (Table-2).

Table 2: Properties of the items and internal consistency of the final scale

\begin{tabular}{|c|c|c|c|c|c|}
\hline Item No. & Items & $\mathbf{M}$ & SD & $\mathbf{r}$ & $\alpha$ \\
\hline 2. & $\begin{array}{l}\text { I usually manage one way or another (प्राय: मैं किसी न किसी प्रकार से कार्य संपन्न } \\
\text { कर लेता/लेती हूँ|) }\end{array}$ & 3.8630 & 1.02337 & .392 & .773 \\
\hline 3. & $\begin{array}{l}\text { I am able to depend myself more than anyone else (अन्य की तुलना में, मैं स्वयं पर } \\
\text { अधिक निर्भर हूँ।) }\end{array}$ & 3.8650 & 1.16453 & .335 & .778 \\
\hline 4. & $\begin{array}{l}\text { Keeping interested in things is important to me (चीजों में रूचि बनाये रखना मेरे लिए } \\
\text { महत्वपूर्ण है।) }\end{array}$ & 3.8820 & 1.11684 & .376 & .774 \\
\hline 5. & $\begin{array}{l}\text { I can be on my own if I have to (यदि मुझे कार्य करना ही हो तो मैं स्वत: कर } \\
\text { सकता/सकती हूँ।) }\end{array}$ & 4.0330 & 1.07288 & .451 & .768 \\
\hline 6. & $\begin{array}{l}\text { I feel proud that I have accomplished things in my life (मुझे इस बात पर गर्व का } \\
\text { अनुभव होता है कि मैने जीवन में कई कार्यो को सम्पन्न किया है।) }\end{array}$ & 3.7710 & 1.18826 & .395 & .773 \\
\hline 7. & I usually take things in stride (मैं प्राय: चीजों को शीघ्रता से करता/करती हूँ।) & 3.5590 & 1.18909 & .393 & .773 \\
\hline 10. & I am determined (मैं हढ़प्रतिज्ञ हूँ।) & 3.6200 & 1.20792 & .403 & .772 \\
\hline 14. & I keep interested in things (मैं चीजों में रूचि बनाये रखता/रखती हूँ।) & 3.9820 & 1.05109 & .420 & .770 \\
\hline 16. & $\begin{array}{l}\text { My belief in myself gets me through hard times (मेरा आत्मविश्वास मुझे बुरे वक्त को } \\
\text { पार करा देता है।) }\end{array}$ & 3.9530 & 1.04397 & .421 & .770 \\
\hline 17. & $\begin{array}{l}\text { In an emergency, I'm someone people generally can rely on (किसी आपात स्थिति } \\
\text { में, मैं एक ऐसा/ऐसी व्यक्ति हूँ, जिसपर लोग सामान्यत: भरोसा कर सकते हैं।) }\end{array}$ & 3.8440 & 1.06527 & .401 & .772 \\
\hline 18. & $\begin{array}{l}\text { I can usually look at a situation in a number of ways (किसी परिस्थिति को मैं अलग- } \\
\text { अलग नजरिये से देख सकता/सकती हूँ।) }\end{array}$ & 3.7350 & 1.09177 & .363 & .775 \\
\hline 19. & My life has meaning (मेरा जीवन उद्देश्यपूर्ण है।) & 4.0050 & 1.11992 & .419 & .770 \\
\hline 20. & $\begin{array}{l}\text { When I'm in a difficult situation, I can usually find my way out of it (जब मैं किसी } \\
\text { कठिन परिस्थिति में होता/होती हूँ तो मैं सामान्यत: बाहर निकलने का रास्ता तलाश लेता/लेती } \\
\text { हूँ।) }\end{array}$ & 3.9110 & 1.00702 & .377 & .774 \\
\hline 21. & $\begin{array}{l}\text { I have enough energy to do what I have to do (मुझे जो करना होता है उसके लिए मेरे } \\
\text { पास पर्याप्त उर्जा होती है।) }\end{array}$ & 3.9510 & 1.08710 & .463 & .767 \\
\hline
\end{tabular}




\subsection{Confirmatory Factor Analysis (CFA)}

We performed CFA based on the variance - covariance matrix using the AMOS 18 statistical package for testing the five-factor model. Parameters were estimated for the CFA model based on the maximum likelihood procedure (sometimes called path analysis) involving fitting the variance and covariance among observed scores. AMOS, therefore, created a covariance matrix, including the variances and covariances among observed scores.

It was estimated to identify the five factor model in order to estimate the model parameters. Factor loadings and the variances and covariances among the errors were used to identify the five-factor model. In conducting CFA, no warning messages were received from AMOS regarding parameter estimates. Based on this information, the five-factor model passed the "rules" for identification.

Following identification of the five-factor model, we examined the assessment of universal fit of the quality of the model in AMOS in order to support or reject its appropriateness for the population examined. The next step was to illustrate the observed (items) and unobserved (factors) in the hypothesized model (Figure 1). The observed variables are represented as rectangles, ellipses represent the unobserved variables, and the circles represent measurement error. The measurement model consists of five interrelated constructs: preservence, self-reliance, interest in life, self-confidence \& accomplishment, and self-determination. The arrow between the unobserved variable and the observed variable represents a regression path, and its number represents the standardized regression weight. The double-headed arrows represent the correlation between two unobserved variables (factor covariance) of the model.

Table 3: Goodness-of-fit indices for the five-factor model of the Resilience Scale $(\mathrm{N}=1000)$

\begin{tabular}{|c|c|c|c|c|c|c|c|}
\hline Model & $\chi \mathbf{2}$ & $\mathbf{d f}$ & $\mathbf{p}$ & $\chi \mathbf{2} / \mathbf{d f}$ & GFI & CFI & RMSEA \\
\hline $\begin{array}{c}\text { Total } \\
\text { sample } \\
(\mathrm{N}=1000)\end{array}$ & 130.348 & 67 & .000 & 1.945 & .982 & .968 & .031 \\
\hline
\end{tabular}

The R14 presented a $\chi 2 / \mathrm{df}=1.945(\chi 2 / \mathrm{df}$ inferior to 2 was considered good) \& $\mathrm{p}<.000$, which are good. Quality adjustment indices were very good, GFI .982 (varies between 0 and 1, considering that the closer to 1 , the better the adjustment of the model); CFI 968 (good when superior to .90 ) and RMSEA .031 (values between .05 and .10 were good and values lower than .05 were considered very good) (Maroco, 2010).

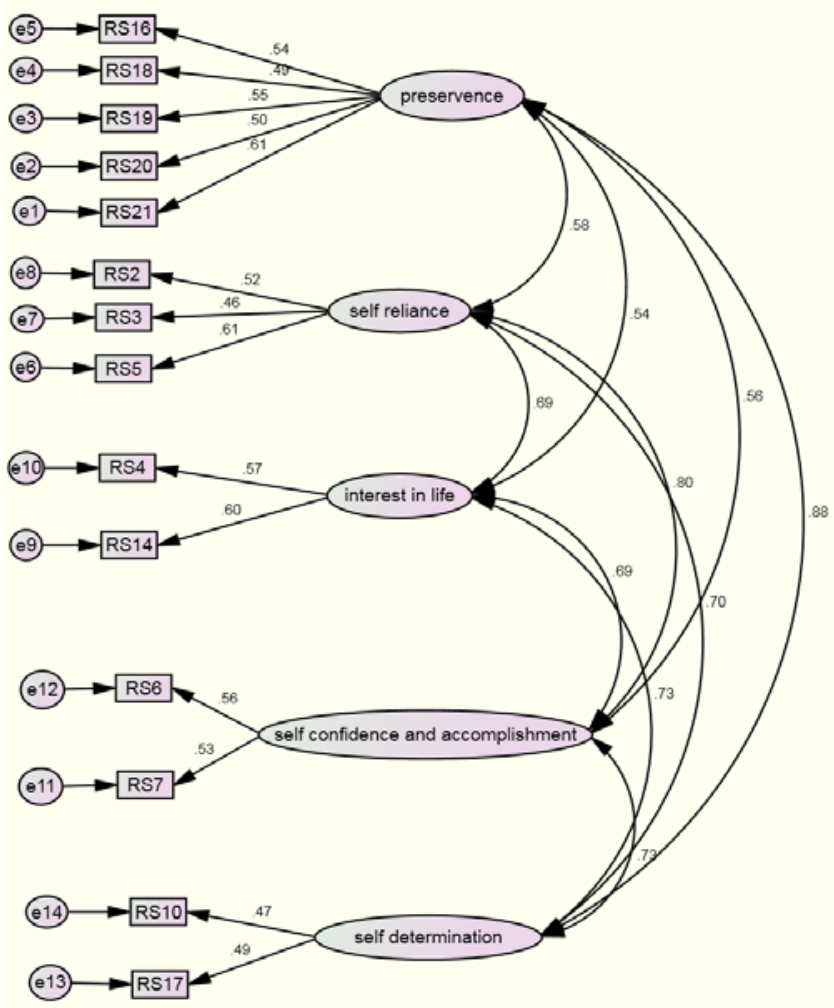

Figure 1: Hypothesized 14-item model of factorial structure of the Resilience Scale

\section{DISCUSSION}

The present study's main objective was to adapt and explore the psychometric properties of the adapted 14 items of the Resilience scaleR25 developed by Wagnild \& Young (1993) on Hindi speaking state's adolescents of India.

In the present investigation, a five factor structure was found, consisting of 14 items, which differs from the original scale proposal by Wagnild and Young (1993), but is in line with what was proposed by Wagnild (2009a). This scale is composed of five factors that explain $55.904 \%$ of the variance. The factorial structure obtained showed appropriate values concerning item-total correlations and their respective Cronbach's alfa values. Itemtotal correlations found were greater than .30, and Cronbach's alfa was considered reliable, i.e., 0.78 (Pestana and Gageiro, 2003)

Based on the data, we generated a five-factor model using Varimax rotation. To determine the psychometric properties of R14, the specification of the five-factor model; assessment of fit between the model and observed variables (items) were presented through the CFA approach. The measurement model consists of five interrelated constructs: preservence, self-reliance, interest in life, self-confidence \& accomplishment, and self-determination. The R14 presented a good $\chi 2 / \mathrm{df}$ score (1.945) and good quality adjustment indices, i.e., GFI .982; CFI .968, and RMSEA .031 (Maroco, 2010). Consequently, we could conclude that R14 items provide a valid and reliable scale to assess adolescents' ability to deal with change or adversity effectively.

\section{LIMITATIONS OF THE STUDY}

It is essential to consider some limitations of this study. Since this scale is meant for adolescents only, it is advisable to reassess this scale's psychometric properties for other populations in the Indian context. It was administered in Hindi speaking states of India. Thus, it is also advisable that reassess the psychometric properties of this scale in other states of India. R14 items provide a valid and reliable scale to effectively assess adolescents' ability to deal with change or adversity.

\section{CONCLUSIONS}

This study's results supported the usefulness of the R14 as a brief, reliable, and psychometrically sound scale for measuring adolescents' resilience. We recommended that the scale be revalidated on different populations and other states except Hindi speaking states to measure resilience.

\section{REFERENCES}

Felgueiras, M. C., Festas, C., \& Vieira, M. 2010. Adaptação e validação da resilience scale de Wagnild e Young para a cultura Portuguesa [Adaptation and validation of the resilience scale de Wagnild e Young for the Portuguese culture]. Cadernos de Saúde, 3(1), 73-80

Gosling, S.D., Rentfrow, P.J., \& Swan Jr. W.B. 2003. A very brief measure of the Big-five personality domains. Journal of Research in Personality, 37 (6), 504-528.

Hanewald R.2011. Reviewing the Literature on "At-Risk" and Resilient Children and Young People, Australian Journal of Teacher Education Volume 36, 2, March 2011.

Jokar B. 2007. Mediating role of resiliency in emotional intelligence and general intelligence, life satisfaction. Journal of Contemporary Psychology, 2, 3-12.

Khabbaz M, Behjati Z, Naseri M.2011. The relation between social support, coping styles, and resiliency in boy adolescents, applied psychology quarterly, Pp 108-124.

Kiani Dehkordi M.2004. Studying objective and interfering factors of resiliency against addiction in sons of fathers addicted and not addicted to drugs, doctorate thesis, unprinted, Tehran University of welfare and rehabilitation science.

Oliveira, M., \& Machado, T. 2011. Tradução e validação da escala de resiliência para estudantes do ensino superior [Translation and validation of the resilience scale in a sample for students of higher education]. Análise Psicológica, 4(XXIX), 579-591.

Pinheiro, M.R., \& Matos, A.P. 2013a. Avaliação da resiliência em adolescentes portugueses: novos contributos para o estudo das versões longa e breve da Resilience Scale de Wagnild e Young (1993) [Evaluation of Resiliency in Portuguese adolescents: new 
Cultural Communication and Socialization Journal (CCSJ) 2(2) (2021) 43-47

contributions to the study of long and short versions of the Resilience Scale]. Livro de Aras do VIII Simpósio Nacional de Investigação em Psicologia, 806-815. Editora, Associação Portuguesa de Psicologia.

Pinheiro, R., \& Matos, A. P. 2013b. Exploring the construct validity of the two versions of the Resilience Scale in a Portuguese adolescent sample. The European Journal of Social \& Behavioural Sciences, 2(10), 178-189. doi:10.15405/Future Academy/ejsbs (23012218).2012.2.5

Smiley RK. 2011. Model development to measure resilience in adolescents, Ph.D. thesis. University of Missoury, Kansas.

Stokowski, P., Reynolds, A., \& Bezruczko, N. 2000. Resilience and protective factors in adolescence: An autobiographical perspective from disadvantaged youth. Journal of School Psychology, 37 (4),
$425-448$.

Wagnild, G. 2009a. The resilience scale user's guide for the US English version of the resilience scale and the 14-item resilience scale (RS14). Worden, MT: Resilience Center.

Wagnild, G., \& Young, H. M. 1990. Resilience among older women. Journal of Nursing Scholarship, 22, 252-255. doi:10.1111/j.15475069.1990. tb00224.x

Wagnild, G., \& Young, H. M. 1993. Development and psychometric evaluation of the Resilience Scale. Journal of Nursing Measurement, 1,165-178.

Windle, G., Bennett, K. M., \& Noyes, J. 2011. A methodological review of resilience measurement scales. Health and Quality of Life Outcomes, 9:8. doi:10.1186/1477-7525-9-8

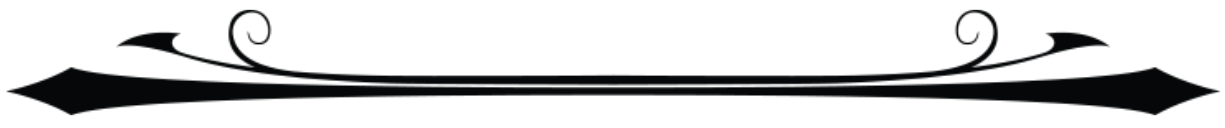

Cite the Article: Shweta Singh and Ajai Pratap Singh (2021). Validation of The Factor Structure of The Hindi Version of Resilience Scale of

Adolescents in The Indian Context. Cultural Communication and Socialization Journal, 2(2): 43-47. 